\title{
Changes of Species Richness in Heathland Communities over 15 Years following Disturbances
}

\author{
L. Calvo, R. Tárrega, and E. Luis \\ Area of Ecology, Faculty of Biological and Environmental Sciences, University of León, 24071 León, Spain \\ Correspondence should be addressed to L.Calvo, leonor.calvo@unileon.es
}

Received 13 October 2011; Revised 16 December 2011; Accepted 16 December 2011

Academic Editor: Piermaria Corona

Copyright $\odot 2012$ L. Calvo et al. This is an open access article distributed under the Creative Commons Attribution License, which permits unrestricted use, distribution, and reproduction in any medium, provided the original work is properly cited.

The aim of this study was to define the species richness patterns over a period of 15 years during the vegetation recovery process after disturbances (burning, cutting and ploughing) in heathlands. Three communities were selected: two dominated by Erica australis and one dominated by Calluna vulgaris. The alpha and gamma diversity patterns were site specific and influenced by the ecological traits of dominant shrub species. The shrubland dominated by Erica australis, typical resprouters with a fast regeneration, showed the highest values of alpha and gamma diversity during the first 7 years of regeneration. The heathland dominated by Calluna vulgaris, an obligate seeder, had a contrasting pattern of alpha and gamma diversity, as the highest values appeared from year 7 until year 14. Thus, the speed of regeneration of the dominant shrub species could be the main factor affecting structural parameters in these communities. Species richness patterns did not vary in relation to the different types of perturbation. Cutting and burning would be the most suitable forestry management strategies to conserve Erica australis heathlands, but burning is more appropriate in Calluna vulgaris ones because cutting modified this community.

\section{Introduction}

Maintaining plant diversity is a central goal in the management of biodiversity throughout the world $[1,2]$. In some ecosystems like Mediterranean ones, biodiversity is of particular interest. Factors driving plant diversity in all ecosystems are of both theoretical and practical concern [3]. In Mediterranean ecosystems the anthropogenic activities like cultivation, intensive grazing, cutting, firewood exploitation, and wildfires have allowed a remarkable biodiversity to be maintained [4-9].

Heathlands and shrublands currently occupy extensive areas of the Mediterranean region covering a total surface of $110854 \mathrm{~km}^{2}$ [10]. These heathland communities are considered one of the types of forestry system, and according to the second Spanish National Forest Inventory (2IFN) [11] they represent $24 \%$ of the total surface area in Spain. In the same way, and according to the third National Forest Inventory (3IFN) [12], in the NW of the Iberian Peninsula (Leōn province) the surface covered by heathlands represents $45 \%$ of the total forestry surface [13]. In some parts of the Mediterranean Basin, heathlands had been considered marginal lands as they have low productivity and economic value [14]. For this reason, they have often been replaced by forests through extensive afforestation programmes, especially in Spain [15] and Portugal [16].

In spite of the low economic values attributed to shrublands, they represent distinctive European habitats for their biodiversity, as well as their aesthetic and cultural values [17]. Overall, they have significant properties as ecosystems and provide several ecosystem services. So, many of these heathland communities are protected under EU designation (Habitats Directive 92/43/EEC), and for this reason it is necessary for forestry managers to define effective management practices for their conservation [18]. In the future, heathland ecosystems could be threatened as a consequence of large-scale human activities (use of artificial fertilizers, rural abandonment, wildfires) that have led to a major decline in their area $[18,19]$. So, it would be very important to understand any traditional management that helps to define the most suitable management strategies.

These shrubland communities have traditionally been managed by fire to create open areas for grazing [14]. The second most common type of perturbation, in these 
communities, is cutting, the products of which have different purposes: domestic fuel, fertilisers [20]. Thirdly, the shrublands have been ploughed up in order to create arable land, a common practice in the province of León during the 1960s. As time passed and agrarian policy changed, these farming areas were abandoned in the 1970s. After burning, cutting, and when cultivated lands have been abandoned, the community begins a secondary succession process, which has been identified as autosuccession in these formations $[14,21]$. Vegetation recovery after these perturbations is started by seedling recruitment from a dormant seed bank or by resprouting from belowground vegetative buds [2224]. Community regeneration processes differ depending on the regenerative strategies utilised by the dominant shrubs. Communities dominated by strong resprouters like Erica australis [14] regenerate faster than communities dominated by seeders, such as Calluna vulgaris in the heathlands of Leōn province (NW Spain) [15]. Another factor to consider is the type of disturbance and its legacy.

Therefore, after burning and cutting, the vegetation could regenerate using both mechanisms, resprouting and germination; however, after ploughing species can only use germination. This can limit those species with a low germination capacity. These differences in types of vegetation regeneration after perturbation, mainly of the dominant shrubs, and changes in competitive ability when conditions change may influence structural parameters in the heathland. Ecosystem disturbance is associated with vegetation changes, such as floristic composition and the structure of vegetation communities [25], since during this process of regeneration after disturbances there is a change in species or groups of species [26]. The most direct method of documenting succession changes in plant diversity involves measuring changes at a single site through time. However, because this involves long time scales, few studies have used this approach [26].

The response of ecosystems to a disturbance is of crucial importance for conservation management, especially when the objective is to maintain their biodiversity, since the relationship between species diversity and succession is not well understood in Mediterranean areas [27]. These types of studies help to answer the question of how the structure of these communities (species richness and diversity patterns) is affected by management practices.

The aim of this study is to define the trends in species richness patterns over a period of 15 years during the vegetation recovery process after disturbances in heathland characterized by great homogeneity prior to disturbances. Specifically, we assess whether there are differences in the $\alpha, \gamma$, and $\beta$ diversity patterns after burning, cutting, and ploughing, which represent the most frequent disturbances experienced in heathland in the northwest of Spain. We also test whether the heat-dominant species with different regeneration strategies (resprouting versus germination) affect the diversity patterns. The results obtained in this research would help to define the suitable forestry management strategies for maintaining high diversity values in these communities and how their structure will be affected by these management practices.

\section{Materials and Methods}

Three heathlands situated in the province of León (NW Spain) (Figure 1) were chosen for the study. All had a very homogeneous structure. The zone A (Table 1) showed Erica australis as a dominant species (cover over 75\%), while other woody species (Calluna vulgaris, Halimium alyssoides, Halimium umbellatum, and Thymus zygis) had less than 1\% cover. Cover of herbaceous species was also less than $1 \%$ prior to disturbance. The second, zone B (Table 1), together with Erica australis, other woody species were also widely represented by the following chamaephytes: Arctostaphylos uva-ursi, Erica umbellata, Calluna vulgaris, Chamaespartium tridentatum, Halimium alyssoides, and Halimium umbellatum and by the phanerophyte Quercus pyrenaica in a shrubby state. Cover of herbaceous species was less than $1 \%$ prior to disturbance. The soil of both zones was classified as a humic cambisol [28]. Both zones are included in the Mediterranean climatic zone as they experience a period of summer drought between July and August. Mean annual precipitation values are $840 \mathrm{~mm}$ and mean annual temperature is $10.3^{\circ} \mathrm{C}$, mean minimum in the coldest month is $-1.1^{\circ} \mathrm{C}$ and mean maximum in the warmest month is $26.9^{\circ} \mathrm{C}$ [29].

The third, zone C (Table 1), is dominated by Calluna vulgaris (cover greater than 80\%), other woody species present were Erica tetralix, Erica australis, and Vaccinium myrtillus (mean cover less than 5\%). Herbaceous species were not abundant (total cover less than 1\%). The soils are rankers and the climate is typically continental (mean annual precipitation is $1320 \mathrm{~mm}$, without an arid period, mean annual temperature is $5.5^{\circ} \mathrm{C}$, mean minimum in the coldest month is $-3.5^{\circ} \mathrm{C}$ and mean maximum in the warmest month is $\left.18.5^{\circ} \mathrm{C}\right)$.

A system of three plots, each measuring $100 \mathrm{~m}^{2}$ (Figure 1), with a $3 \mathrm{~m}$ wide corridor in-between was established in each study area. One of the plots was burned in summer simulating a wildfire; no aboveground biomass survived the burning. In the second plot all the woody aboveground biomass was cut to ground level and the third plot was ploughed by mechanical means in summer 1986 (with a tractor, ploughing depth was $50 \mathrm{~cm}$ ). All the experimental treatments were carried out during the summer period between 1985 and 1986 (in zone B all the experimental treatments were carried out in July 1985. In zone A cutting and burning were performed in 1985 and ploughing in 1986. In zone C cutting was in 1985 and burning and ploughing in 1986). All the vegetation stumps were eliminated by ploughing treatment in order to eliminate vegetative resprouting. To record changes in the plant communities 5 quadrats of 1 square meter were randomly chosen in each plot during the first sampling visit and these were sampled annually in June for 15 years (data from the first year after disturbances were not available because the regeneration was practically zero). In each sampling unit the percentage cover of all the species present (herbaceous and woody) was visually estimated, always by the same research team.

2.1. Data Analysis. The measures of diversity were carried out with the richness index $(S)$, because we considered 
TABLE 1: Characteristics of the three study zones.

\begin{tabular}{ccccccc}
\hline & Type of heathland & $\begin{array}{c}\text { Altitude } \\
(\mathrm{m})\end{array}$ & Localization & Slope & Type of soils & Climate \\
\hline Zone A & $\begin{array}{c}\text { Dry heathland dominated } \\
\text { by Erica australis }\end{array}$ & 1000 & $42^{\circ} 43^{\prime} 52^{\prime \prime} \mathrm{N} ; 5^{\circ} 8^{\prime} 9^{\prime \prime} \mathrm{W}$ & Flat & Humic cambisol & Mediterranean \\
Zone B & $\begin{array}{c}\text { Dry heathland dominated } \\
\text { by Erica australis }\end{array}$ & 1150 & $42^{\circ} 41^{\prime} 47^{\prime \prime} \mathrm{N} ; 5^{\circ} 8^{\prime} 14^{\prime \prime} \mathrm{W}$ & Flat & Humic cambisol & Mediterranean \\
Zone C & $\begin{array}{c}\text { Wet heathland dominated } \\
\text { by Calluna vulgaris }\end{array}$ & 1600 & $43^{\circ} 5^{\prime} 5^{\prime \prime} \mathrm{N} ; 5^{\circ} 21^{\prime} 1^{\prime \prime} \mathrm{W}$ & Flat & Rankers & Continental \\
\hline
\end{tabular}

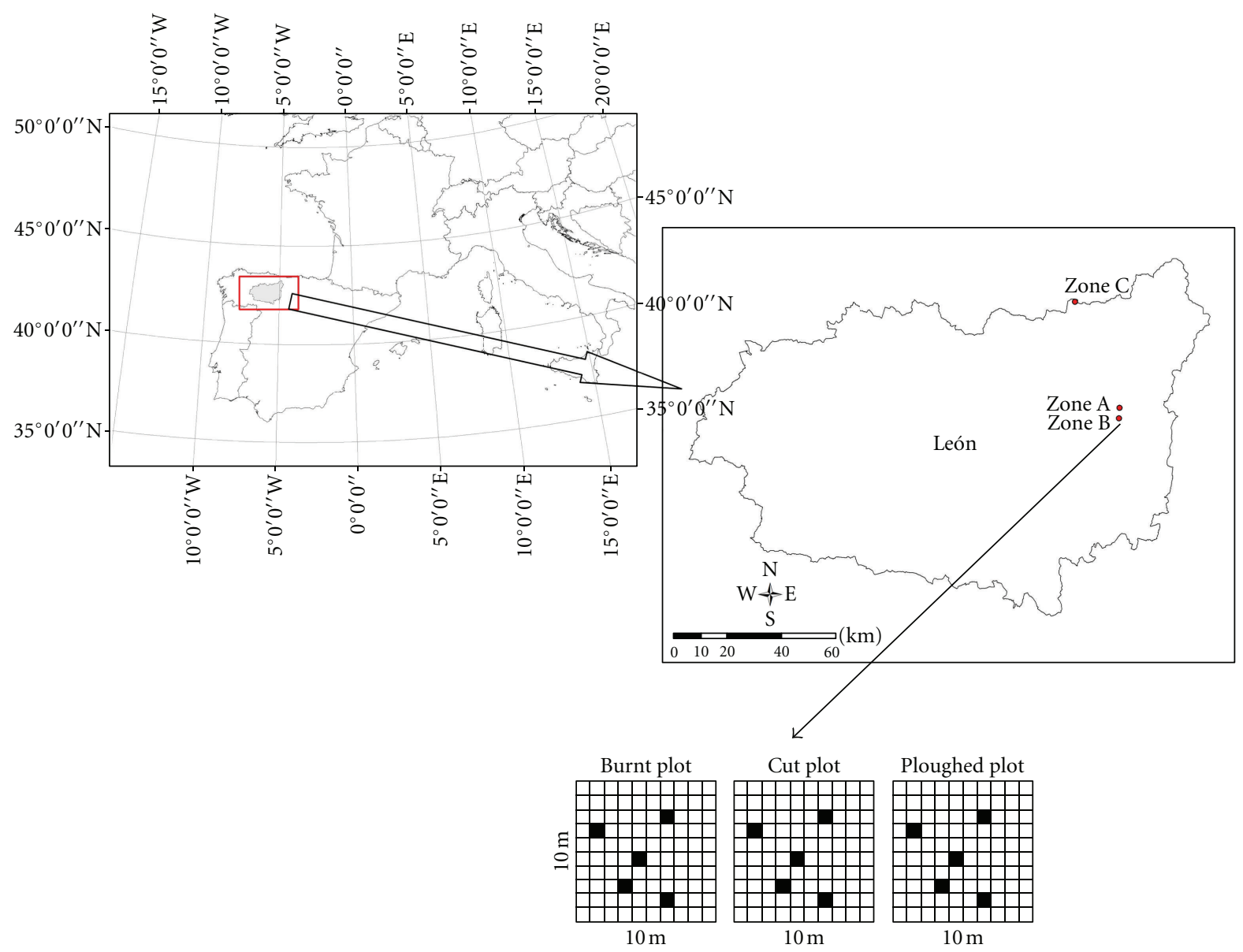

FIgURE 1: Location of the experimental study zones. Structure of the sampling plots.

both woody and herbaceous species. This was calculated on different spatial scales, beginning with $S_{\alpha}$ on a small scale (per quadrat, or $\mathrm{m}^{2}$ ) $[30,31] . S_{\alpha}$ was calculated as the mean of the number of species found per quadrat in each study plot. Richness was calculated on a community scale for each study plot, where $S_{\gamma}$ (from the joint consideration of the 5 samples carried out in each study plot) is the total species number found in each study plot. Finally, in order to determine pattern diversity in each plot we calculated $S_{\beta}$ using the Whittaker formula [30]: $S_{\beta}=\left(S_{\gamma} / S_{\alpha}\right)-1$.

Temporal tendencies in life forms, woody, annual, and perennial herbaceous species richness were analysed.
The effects of experimental disturbances (burning, cutting, and ploughing) on cover of the dominant woody species and $S_{\alpha}$ (dependent variables) were tested using a nested repeated measures (time $=13$ years) ANOVA, with zones $(\mathrm{A}, \mathrm{B}$, and $\mathrm{C})$ nested within experimental disturbances. Assumptions of normality and homogeneity of variances were checked, and dependent variable (\% cover of dominant woody species) was arcsine-square root transformed. Statistical test were carried out using Statistical Program for the Social Sciences 11.5 (SPSS Inc., 1989-2002).

Canonical correspondence analysis (CCA) was performed using CANOCO program [32] to determine the 
TABLE 2: Results of the nested repeated measures ANOVA test the effect of treatments (burning, cutting, and ploughing) in the mean cover of dominant species, nesting zones (A, B, and $\mathrm{C}$ ) into treatments.

\begin{tabular}{lcccc}
\hline & SS & d.f. & $F$ & $P$ \\
\hline Treatments & 73335.23 & 2 & 1.18 & 0.32 \\
Zones (treatments) & 96457.7 & 6 & 7.33 & $<0.01$ \\
Error & 85647.73 & 36 & 80.83 & $<.23$ \\
Time (repeated measures) & 97956.3 & 12 & 3.94 & $<0.01$ \\
Time $*$ Treatments & 24819.9 & 24 & $<0.01$ \\
Time $*$ Zones (treatments) & 337778.6 & 72 & 432 & \\
Error & 60080.98 & & & \\
\hline
\end{tabular}

effects of experimental treatments in plant species composition. Species appearing in less than $5 \%$ of total sampling (less than six samplings plots) were not used in this analysis. The environmental variables considered were: time of recovery, experimental treatments (burning, cutting, and ploughing), and zones (A, B, and C).

In order to establish whether there were general tendencies in structure in the postdisturbance recovery in the three heathlands, principal component analysis was carried out using 7 variables: cover of dominant woody species (Dom.), number of woody species $(W)$, number of perennial $(P)$ and of annual herbs $(A)$, and $S_{\alpha}, S_{\gamma}, S_{\beta}$. The correlation between time after perturbation and the 7 variables was analysed using the Pearson coefficient. The correlation among the 7 variables was also carried out by a partial correlation, controlling the time to avoid the autocorrelation pattern. Statistical tests were carried out using Statistica 6.0.

\section{Results}

Cover value changes of the dominant woody species in time (Figure 2) after the experimental treatments (burning, cutting, and ploughing) showed no common patterns in relation to the type of disturbance, but mainly depended on the dominant species. Significant differences were not detected (Table 2) among treatments but there were in zone (nested into treatment). Cover values changed significantly in time and there was a significant interaction between this repeated measure and the other two factors (experimental treatments and zones). Calluna vulgaris in zone $\mathrm{C}$ showed low cover percentages during the first few years of regeneration after the three disturbances, although a significant increase in time was observed from the ninth year. Calluna vulgaris cover at the end of the study period was smaller in the cut plot than in the other two. The other two study zones, A and B, with the same dominant woody species, Erica australis, showed similar changes in the cover of this species after burning and cutting, though there were differences after ploughing. In zone A Erica australis cover was similar in the three plots and tended to increase in time. Likewise, in zone B an increase in Erica australis cover was observed in time. There were also differences among experimental treatments with the ploughed plot showing less cover than the others throughout the study period.
TABle 3: Results of the nested repeated measures ANOVA test the effect of treatments (burning, cutting, and ploughing) in $S_{\alpha}$, nesting zones $(\mathrm{A}, \mathrm{B}$, and $\mathrm{C})$ into treatments.

\begin{tabular}{lcccc}
\hline & SS & d.f. & $F$ & $P$ \\
\hline Treatments & 805.79 & 2 & 11.07 & $<0.01$ \\
Zones (treatments) & 1628.359 & 6 & 7.45 & $<0.01$ \\
Error & 1309.96 & 36 & & \\
Time (repeated measures) & 1383.35 & 12 & 30.17 & $<0.01$ \\
Time $*$ Treatments & 212.13 & 24 & 2.31 & $<0.01$ \\
Time $*$ Zones (treatments) & 2403.64 & 72 & 8.73 & $<0.01$ \\
Error & 1650.41 & 432 & & \\
\hline
\end{tabular}

In relation to diversity values $\left(S_{\alpha}\right)$ (Figure 2 and Table 3 ), significant differences between treatments were observed. $S_{\alpha}$ changed significantly in time, and there was a significant interaction between this repeated measure and the other two factors (experimental treatments and zones). In zones $\mathrm{A}$ and $\mathrm{B}$ dominated by Erica australis, the highest values appeared 4-5 years after burning, cutting, and ploughing and then tended to decrease. However, in zone C, dominated by Calluna vulgaris, the highest values appeared later. In zone C there were differences in $S_{\alpha}$ between ploughed and burned plots, with intermediate values in the cut plot. In zone $B$, similar $S_{\alpha}$ patterns were observed in the three plots with higher values during the first 5-6 years. In zone A, $S_{\alpha}$ values were at their maximum during the fourth year. In general, $S_{\gamma}$ patterns (Figure 2) in time were similar to $S_{\alpha}$ in all the study zones. $S_{\beta}$ showed great variability in time and only one common pattern appeared among the three study zones: the values were higher after ploughing than after burning and cutting.

Richness of life forms (Figure 3) showed differences according to treatments and zones. In the three study zones after the three experimental treatments, richness of woody species was almost constant over time. Changes in the richness of the other two life forms (herbaceous perennials and annuals) could be influenced by the richness of woody species and also by the cover of the dominant woody species. In zone $\mathrm{B}$, which presented the highest woody richness over time and in each of the three experimental treatments, the highest richness values corresponded to annual herbaceous 

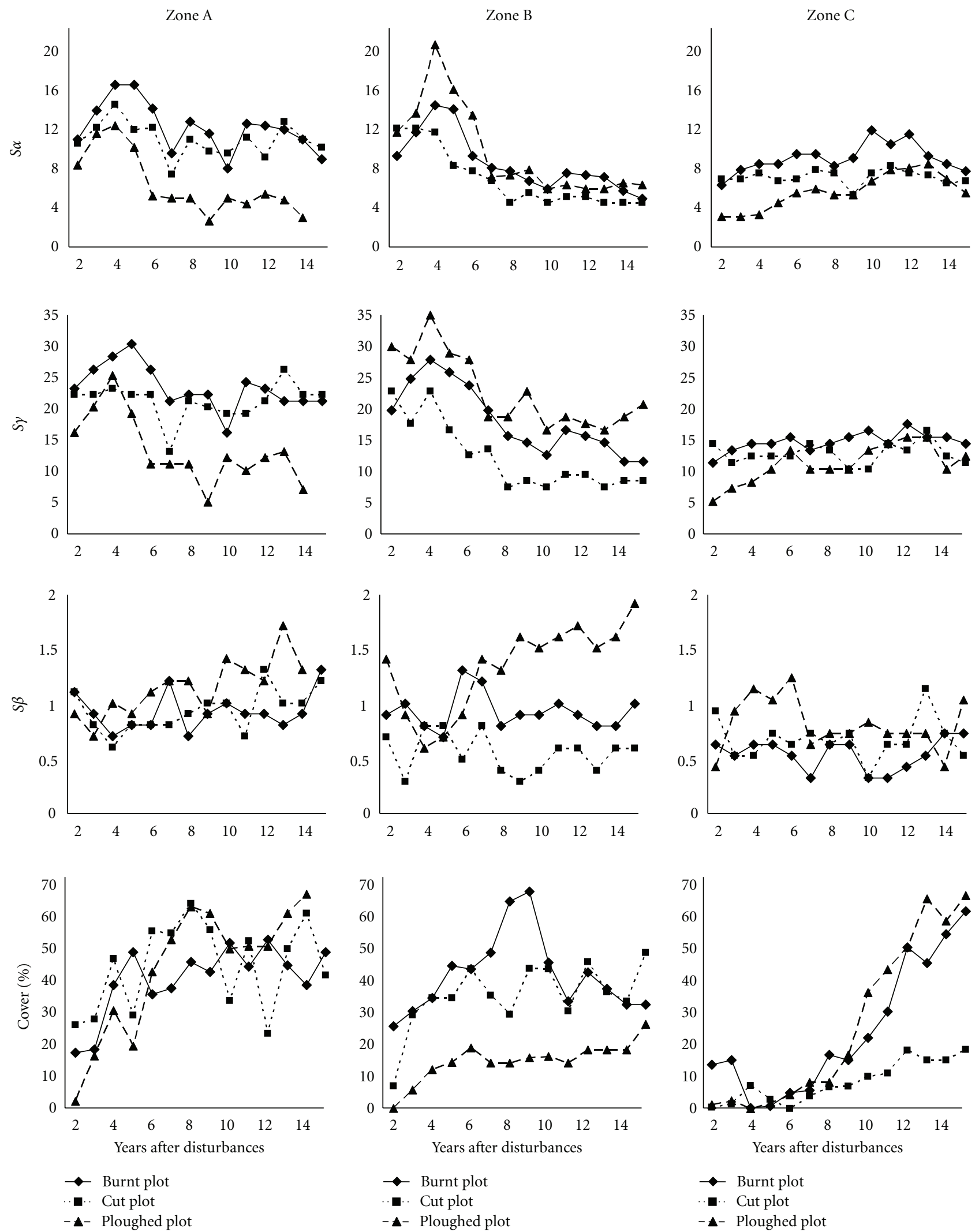

Figure 2: Diversity values $\left(S_{\alpha}, S_{\gamma}, S_{\beta}\right)$ and mean cover of dominant species after burning, cutting, and ploughing in the three study zones (A, B, and C) during the study period (2 to 15 years). 

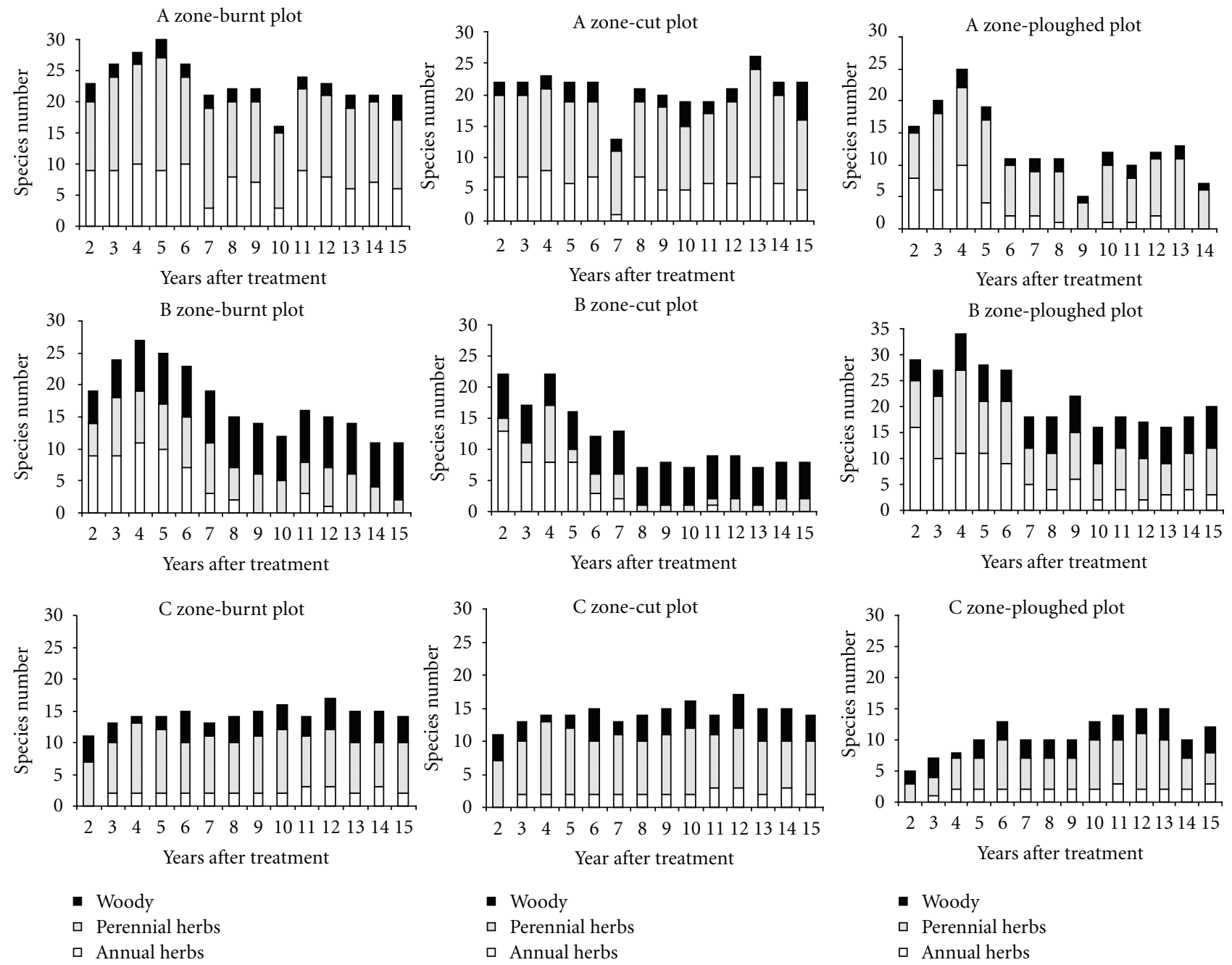

Figure 3: Changes in species richness $\left(S_{\gamma}\right)$ of life forms (woody, perennial herbaceous, annual herbaceous) after burning, cutting, and ploughing in the three zones (A, B, and $\mathrm{C}$ ) during the study period (2 to 15 years).

during the first few years of regeneration, but after eight years they mainly disappeared after burning and cutting and showed a considerable decrease after ploughing. However, in the other two zones, $\mathrm{A}$ and $\mathrm{C}$, where woody richness was lower, annual and perennial herbaceous species did not show important variations over time, except in the ploughed plot A, which showed similar behaviour to that of zone B.

The canonical correspondence analysis (Figure 4) showed a clear differentiation by study zones in relation to the species composition. In this analysis the factor zone showed higher importance than experimental treatments and time after disturbance. For this reason, it was difficult to differentiate a clear effect of treatments and time. Axis I (which explain $46 \%$ of total variance) discriminated between the plots from zone $\mathrm{C}$ and the others, which were associated with the presence of heathland species like Erica tetralix, Juncus squarrosus, Nardus stricta, and Vaccinium myrtillus. Axis II (which explained $25 \%$ of the total variance) differentiated the plots from the zone A situated in the positive side and associated with the woody shrubland species like Erica arborea and Thymus zygis and mainly by herbaceous ones like Centaurea janeri, Daucus carota, Filipendula vulgaris, and Lotus corniculatus. In the negative side of axis II were situated the plots from zone B, which were associated with the presence of shrubland species like Arctostaphylos uva-ursi, Halimium alyssoides, and Erica umbellata. In this zone it was possible to appreciate an ordination of plots related to time after treatments.

Principal component analysis considering the three experimental treatments in time in each study zone showed a common pattern in the three zones, for this reason we only showed results from zone C (Figure 5). There was a tendency to separate treatment (burning, cutting, and ploughing), but there was no clear tendency by time after treatments. Analyzing every treatment separately in each zone, principal component analysis showed common behaviour in zones A and $\mathrm{B}$ and the opposite in zone $\mathrm{C}$ (Figure 6 only represents the results of zones $\mathrm{B}$ and $\mathrm{C}$ ). So, in zones $\mathrm{A}$ and $\mathrm{B}$ the initial regeneration years, characterized by a large number of perennials and annuals herbaceous, higher $S_{\alpha}$ and $S_{\gamma}$, were 


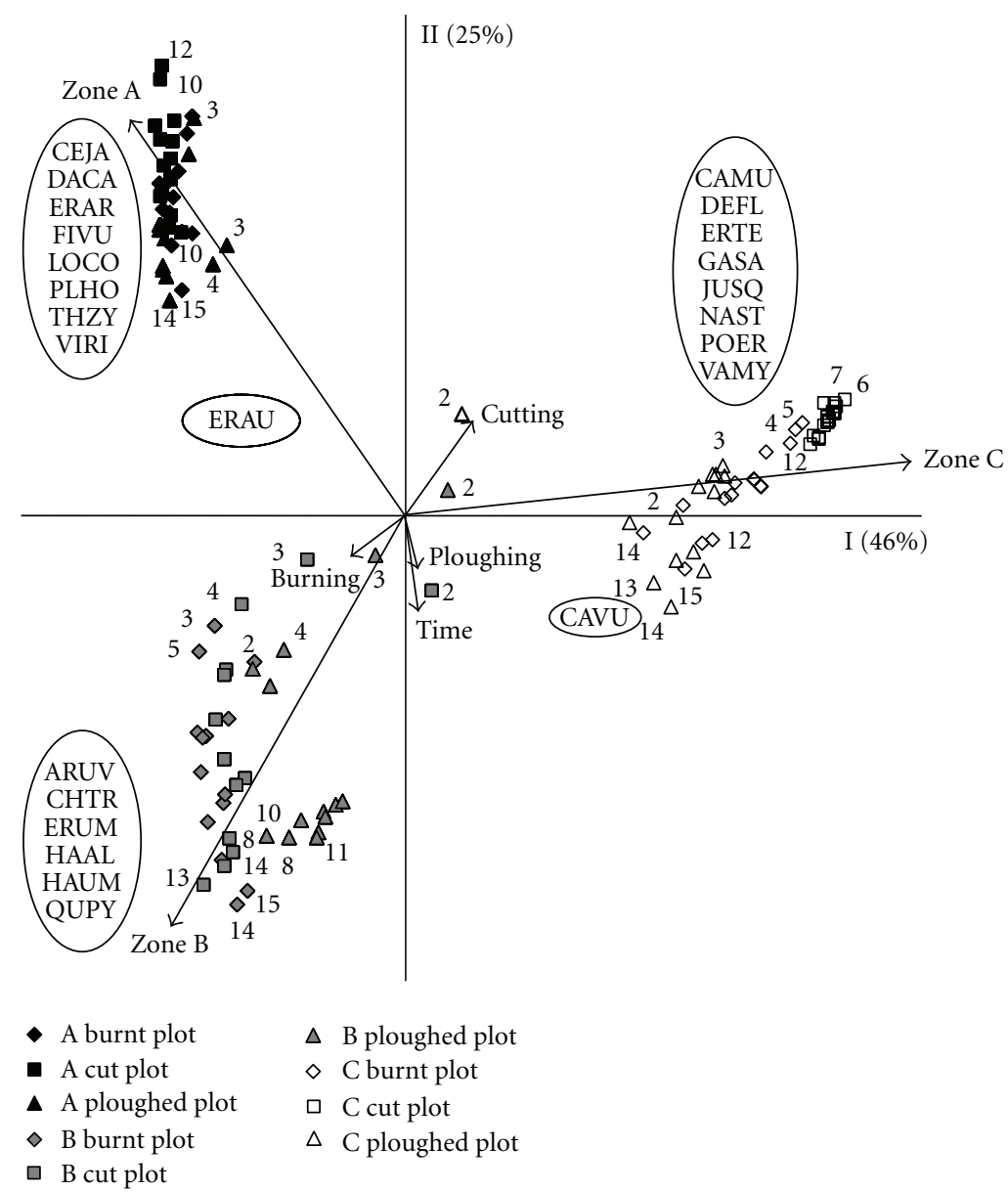

Figure 4: Canonical Correspondence Analysis (CCA) for plant species composition and environment variables (zones, experimental treatments, and time). Variance explained: $46 \%$ axis I, $25 \%$ axis II; Monte Carlo permutation test: $F=35.61 ; P=0.002$. Environmental variables abbreviations are: zone A (dashed shape), zone B (grey shape), zone C (empty shape); burning: diamond; cutting: square; ploughing: triangle; time: numbers representing years after experimental disturbances. Arrows mark the environmental coordinates. Name of species: CAMU: Carex muricata; DEFL: Deschampsia flexuosa; ERTE: Erica tetralix; GASA: Galium saxatile; JUSQ: Juncus squarrosus; NAST: Nardus stricta; POER: Potentilla erecta; VAMY: Vaccinium myrtillus; CAVU: Calluna vulgaris; CEJA: Centaurea janeri; DACA: Daucus carota; ERAR: Erica arborea; FIVU: Filipendula vulgaris; LOCO: Lotus corniculatus; PLHO: Plantago holosteum; THZY: Thymus zygis; VIRI: Viola riviniana; ERAU: Erica australis; ARUV: Arctostaphylos uva-ursi; CHTR: Chamaespartium tridentatum; ERUM: Erica umbellata; HAAL: Halimium alyssoides; HAUM: Halimium umbellatum; QUPY: Quercus pyrenaica.

differentiated from the final regeneration years, which were characterized by a larger number of woody species, higher $S_{\beta}$, and greater cover of dominant woody species (Erica australis).

In zone C (Figure 6) behaviour patterns were the opposite to those of the other zones. There were differences between the initial and final stages of regeneration, but, in this case, the final stages were associated with higher richness of woody, annual, and perennial herbaceous species and high values of $S_{\alpha}$ and $S_{\gamma}$. However, the initial years of regeneration, mainly after ploughing and burning, were characterized by high values of $S_{\beta}$.

A statistically significant positive correlation of time with the cover of the dominant woody species was observed in the total correlation analysis, where the three study zones and the three experimental treatments were considered (Table 4). The same correlation was observed when each study zone was analysed separately for each treatment. Similarly, a significant negative global correlation was observed between time and $S_{\alpha}, S_{\gamma}$ and the number of annual species (Table 4). Annual and perennial herbaceous species showed a great influence on the $S_{\alpha}$ and $S_{\gamma}$ values since the woody values were generally more constant over time.

\section{Discussion}

The impact of shrub perturbation on diversity components was site specific and depended mainly on the woody dominant species as we can observe by the CCA in this study. Vegetation dynamic patterns in postperturbation regeneration are influenced by the fast recovery of the dominant woody species [33]. Many authors have indicated the advantages of vegetative resprouting in terms of the speed of regeneration in comparison with germination [23]. This 


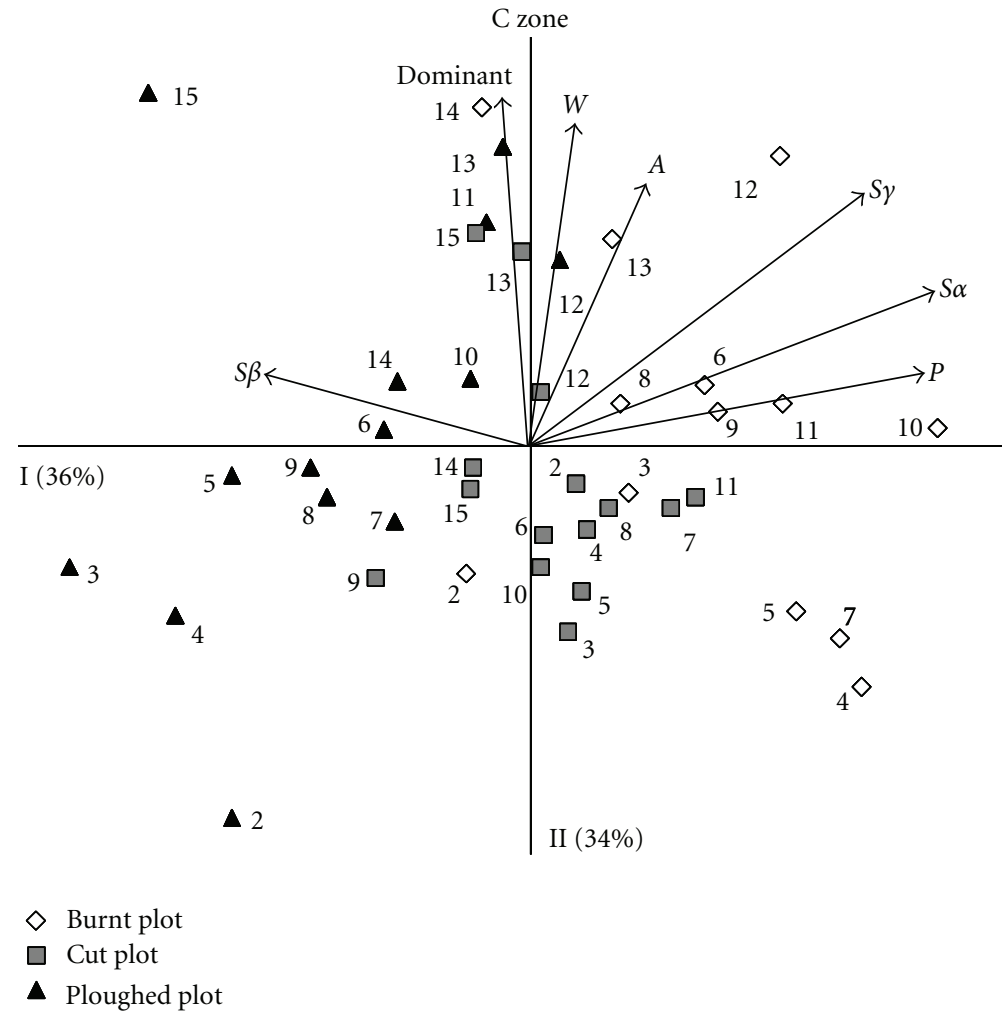

FIGURE 5: Location of variables and samples in the plane defined by the two first axes of the principal components analysis carried out with data from the three plots in zone C. (Annual herbaceous species number $(A)$, perennial herbaceous species number $(P)$, woody species number $(W), S_{\alpha}, S_{\gamma}, S_{\beta}$, and cover of dominant species (Dom.).) Numbers after symbols representing years after experimental disturbances.

TABle 4: Pearson's correlation analysis of time (years) with annual herbaceous species number $(A)$, perennial herbaceous species number $(P)$, woody species number $(W), S_{\alpha}, S_{\gamma}, S_{\beta}$, and cover of dominant species (Dom.) before treatments in each zone, considering all the study plots $\left(N=125\right.$ and the three experimental treatments. Marked $\left({ }^{*}\right)$ correlations are significant at $\left.P<0.05\right)$.

\begin{tabular}{lcccccc}
\hline & Years & $A$ & $P$ & $W$ & $S_{\alpha}$ & $S_{\gamma}$ \\
\hline$A$ & $-0.43^{*}$ & & & & \\
$P$ & -0.15 & $0.53^{*}$ & & & \\
$W$ & 0.16 & 0.05 & $-0.45^{*}$ & & \\
$S_{\alpha}$ & $-0.33^{*}$ & $0.81^{*}$ & $0.68^{*}$ & 0.07 & & \\
$S_{\gamma}$ & $-0.27^{*}$ & $0.89^{*}$ & $0.75^{*}$ & 0.11 & $0.89^{*}$ & $0.31^{*}$ \\
$S_{\beta}$ & 0.13 & $0.23^{*}$ & $0.26^{*}$ & 0.05 & -0.13 & $0.19^{*}$ \\
Dom. & $0.48^{*}$ & 0.17 & 0.17 & -0.04 & $0.19^{*}$ & 0.04 \\
\hline
\end{tabular}

explains differences in diversity patterns $\left(S_{\alpha}, S_{\gamma}\right)$ among the study zones. Zones A and B have the same dominant shrub species, Erica australis, which has a lignotuber that allows it to resprout actively after burning and cutting $[15,34]$ and is also able to regenerate by germination after ploughing $[20,35]$. Therefore, an increase in the number of perennial and annual herbaceous species and consequently high values of diversity $S_{\alpha}$ and $S_{\gamma}$ were found only during the first years of regeneration, when the woody species had not yet reached very high cover values. This increase was recorded during the first 7 years of regeneration in the study zones, as demonstrated in the PCA analysis. In time, the cover of the woody dominant species increased shading conditions at ground level. These shady conditions probably limited the permanence of light-demanding species, mainly herbaceous ones, and modified the values of species richness for the whole community. Many authors have observed an increase in the richness and abundance of herbs in the first years after disturbances $[22,36,37]$, but it is usually restricted to the first five years. The speed with which the dominant species in the studied plots recover conditions the dynamics of the plant community to a great extent.

The diversity pattern observed in zones A and B may also be explained by abiotic changes related to perturbations. Burning creates open spaces, adds nutrients to the soil $[14,35,38]$, and also decreases the amount of litter fall. 
B zone

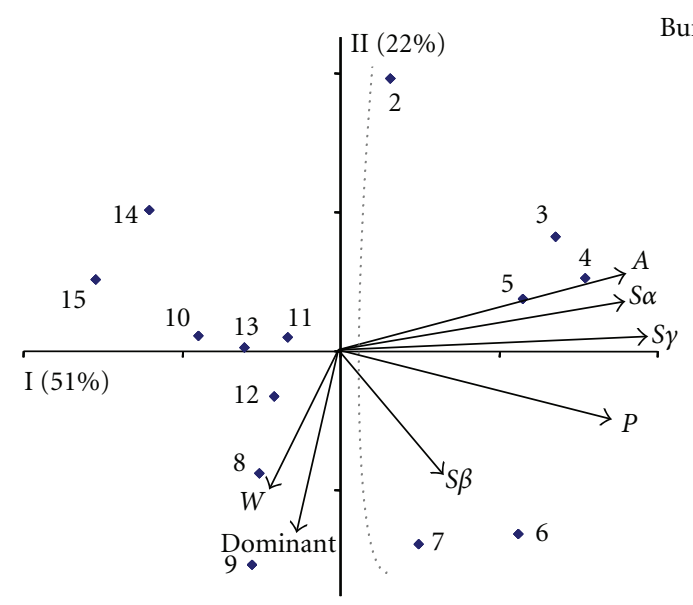

C zone

Burnt plots

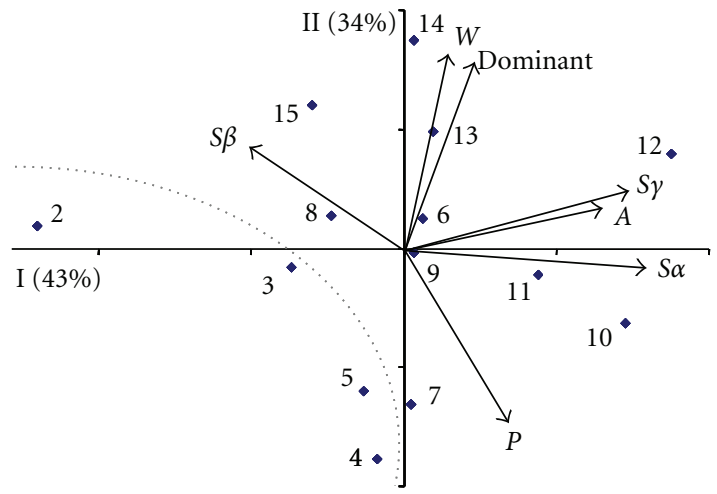

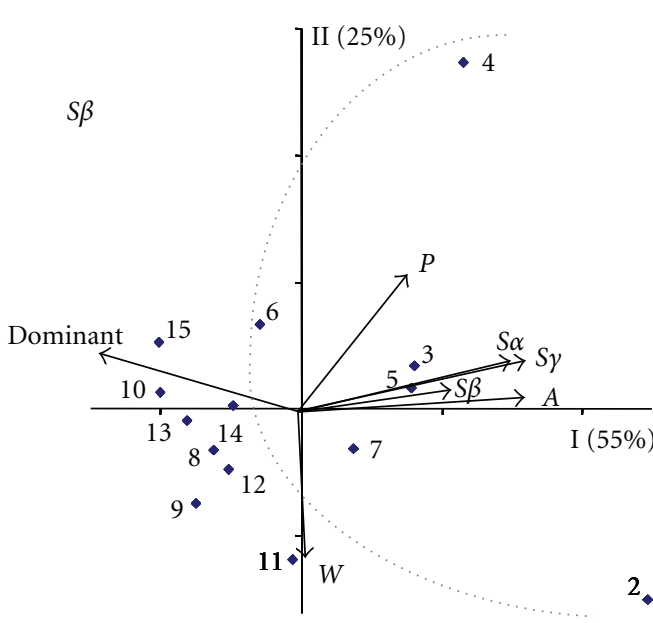

Ploughed plots

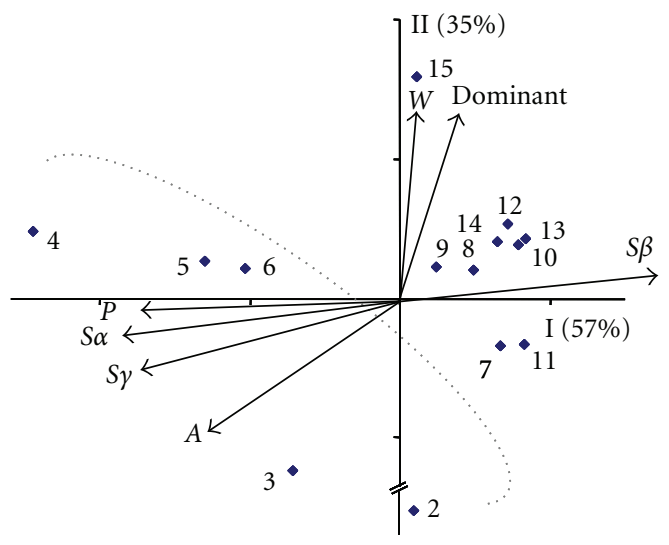

Cut plots

.
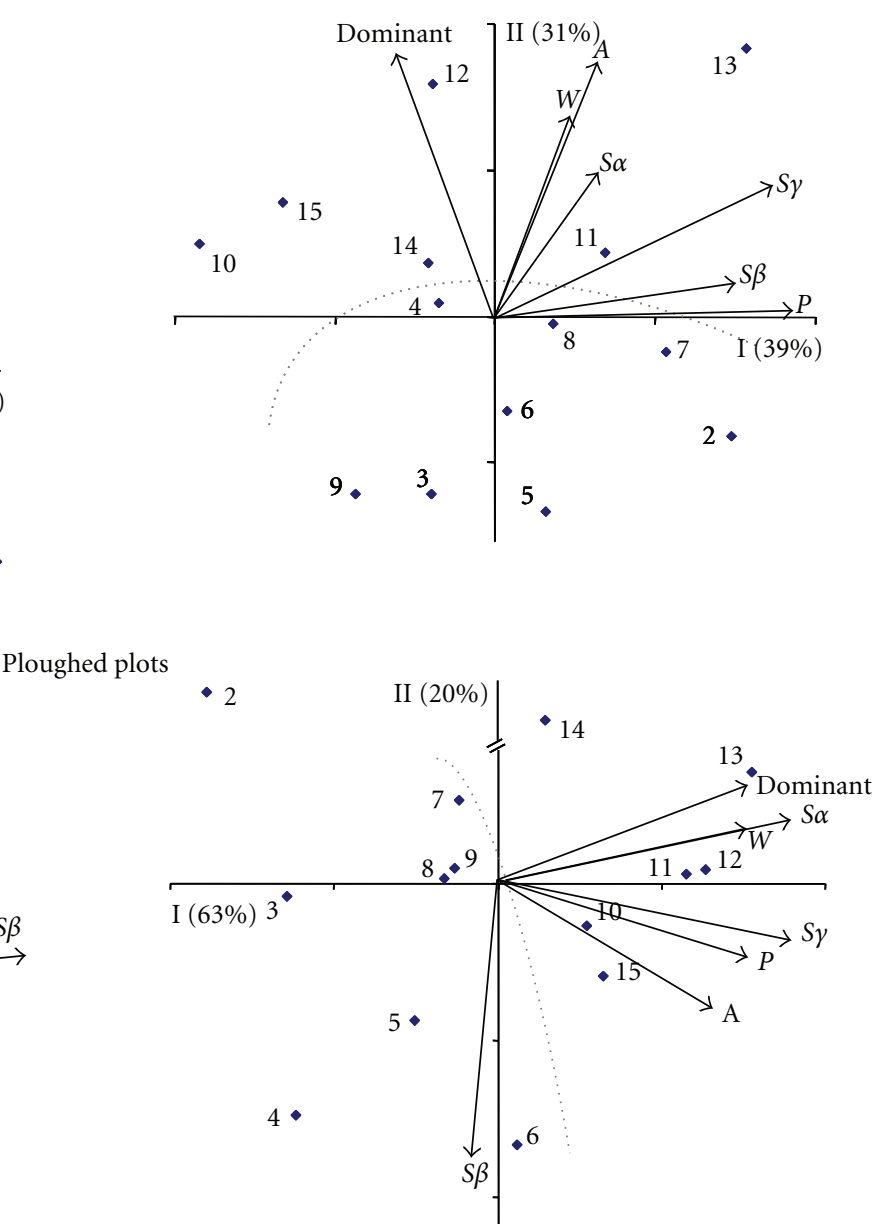

FIGURE 6: Location of variables and samples in the plane defined by the two first axes of the principal components analysis carried out with data from the three plots in zones B and C. (Annual herbaceous species number $(A)$, perennial herbaceous species number $(P)$, woody species number $(W), S_{\alpha}, S_{\gamma}, S_{\beta}$, and cover of dominant species (Dom.).) Numbers representing years after experimental disturbances. 
The removal of the bushy layer resulted in increased light availability at ground level. So, after burning and cutting, regeneration propagules may come from surrounding areas or from the soil seed bank, but regeneration may also occur through the resprouting of the species present in the area. After ploughing or the abandonment of cultivated land, there is a complete removal of every individual or propagule from the more mature and stable original vegetation [33]. In this case, open spaces appear that could be recolonised by species that use germination as a regeneration mechanism $[14,20]$. Therefore, reductions in shrub cover due to the three disturbance (burning, cutting, and ploughing) favour the colonization of new herbaceous species. This effect of higher species richness with increasing light availability at ground level has been documented in other studies [39]. The pool of herbaceous species in each site is determined by the set of available species in the surrounding landscape and the environmental sieve filtering species via abiotic factors (e.g., light and soil chemistry) and biotic interactions (e.g., competition and herbivory) [40,41].

In contrast, the dominant heath species, in zone C, Calluna vulgaris, regenerated only by germination [35] and was slow to recover. In general, a good initial response was observed in this species after burning, because heat stimulates its germination [42-44]. However, there was seedling mortality in the fourth years, probably due to the long period during which this species was under snow [35]. Vegetation dynamics in heathlands seem to depend on the interaction between species attributes and climatic conditions in the area [36]. Germination is not heat stimulated after cutting and ploughing, so Calluna vulgaris regeneration is slower and it allows other woody species, like Vaccinium myrtillus and Erica tetralix, and herbaceous species to spread [35]. In this area, zone $\mathrm{C}$, herbs were abundant in the first ten years after the disturbances and this proliferation of herbs may inhibit the recovery of the dominant woody species when this occurs by germination $[45,46]$. As a result, the patterns of $S_{\alpha}$ and $S_{\gamma}$ diversity differed from those found in the other two study zones. Therefore, in zone $\mathrm{C}$ differences between initial stages and the mature stages, where we found the highest values of diversity, could be explained by the presence of many herbaceous species, in addition to the presence of all the woody species during the later stages. In this zone there was a tendency for diversity values $S_{\alpha}$ and $S_{\gamma}$ to increase with time, whereas in the other two zones, $\mathrm{A}$ and $\mathrm{B}$, these values decreased. In all the study zones, the effects of shrub disturbance had no clear temporal patterns on spatial heterogeneity $\left(S_{\beta}\right)$. In general, we should find a decrease in heterogeneity in time owing to a process of homogenisation associated with the stabilization of the community after disturbances. However, it is probable that this homogenisation effect is only statistically significant at a higher spatial scale, not at plot scale because of the high internal variability [47]. However, ploughing plots showed higher values of $S_{\beta}$ throughout the study period, probably associated with seed species clumped distribution in the soil bank [48].

A comparison of the diversity temporal dynamics after the three disturbances indicates that there are no differences between treatments. The main differences among the study zones are characterised by the different dominant woody species, which have different reproductive strategies and also showed differences in abiotic conditions. Therefore, the zones with resprouter species (Erica australis) had a higher number of herbaceous species, $S_{\alpha}$ and $S_{\gamma}$ during the first years after disturbance, while the zone dominated by germination-dependent species (Calluna vulgaris) showed the opposite.

Disturbances may increase species richness by lowering the dominance of a few species, freeing resources for early successional plants, and providing opportunities for herbaceous species to spread rapidly $[49,50]$. However, from a conservationist perspective, an increase in species richness per se does not always mean improved biodiversity in the system. On the basis of our study, any of the three types of disturbances showed similar patterns of change in the diversity values $S_{\alpha}$ and $S_{\gamma}$; however, ploughing created a very important alteration, not only in vegetation characteristics, but also in soil properties, with a potential risk of erosion. It is likely that the highest global biodiversity in the system could be achieved by promoting a mosaic of different successional stages, whilst trying to avoid more drastic perturbations like ploughing.

Of relevance to forestry managers is the finding that cutting and burning are suitable management strategies to conserve these communities. At the same time, we observed that, in general, marked temporal variations in species diversity following these disturbances showed peaks during the first few years as a result of the diverse postdisturbance herbaceous flora and then declined as the community ages, as occurs in other studies in Mediterranean shrublands [51]. However, the moment when the maximum value in species diversity appears is highly related, among other factors, to whether the site is dominated by resprouters (Erica australis) or seeders (Calluna vulgaris). These results could be used to determine the frequency or the period of time to apply these management strategies in order to conserve heathlands with high values of species diversity and avoid problems of regeneration due to an immature situation [52]. In the case of heathlands dominated by Erica australis, it would be recommendable to use burning or cutting in periods of 7-8 years, because in this period the community has recuperated the original situation [14] and at the same time maintains high diversity values. After this period (7-8 years) senescence effects could be observed in the community [52] with a clear competitive effect of dominant species on the rest of the herbaceous species [21]. However, in the case of the heathlands dominated by Calluna vulgaris the disturbance return period must be longer (minimum 15 years) because they need more time to recuperate. In the same way, the main forestry management strategy in Calluna heathlands would be burning, because after cutting, it is clear that there is an increase in species diversity, but at the same time, there is a change in the dominant woody species (Calluna vulgaris), which is replaced by Erica tetralix [35]; this could modify the characteristics of the heathland community considerably in the long term. 
However, it would be very interesting to complement this type of studies to analyse the response of these communities to different frequencies of disturbance. This would help to define the most adequate perturbation regimes to avoid long-term regimes associated with community senescence or very short-term regimes to prevent natural regeneration that could be considered a form of Intermediate Disturbance Hypothesis (e.g., $[53,54])$.

\section{Acknowledgments}

Research data reported here were obtained in the research projects JCYL LE021A08 and MCYT CGL2006-10998-C0201/BOS. The authors would like to thank anonymous referees for their valuable comments to help to improve this paper.

\section{References}

[1] H. Olff and M. A. Ritchie, "Effects of herbivores on grassland plant diversity," Trends in Ecology and Evolution, vol. 13, no. 7, pp. 262-265, 1998.

[2] F. Ojeda, J. Arroyo, and T. Marañón, "Biodiversity components and conservation of Mediterranean heathlands in southern Spain," Biological Conservation, vol. 72, no. 1, pp. 6172, 1995.

[3] J. E. Keeley and C. J. Fotheringham, "Species-area relationships in Mediterranean-climate plant communities," Journal of Biogeography, vol. 30, no. 11, pp. 1629-1657, 2003.

[4] C. L. Alados, A. Elaich, V. P. Papanastasis et al., "Change in plant spatial patterns and diversity along the successional gradient of Mediterranean grazing ecosystems," Ecological Modelling, vol. 180, no. 4, pp. 523-535, 2004.

[5] J. Blondel and J. Aronson, Biology and Wildlife of the Mediterranean Region, Oxford University Press, Oxford, UK, 1999.

[6] F. de Bello, J. Leps, and M. T. Sebastia, "Grazing effects on the species-area relationship: variation along a climatic gradient in NE Spain," Journal of Vegetation Science, vol. 18, no. 1, pp. 25-34, 2007.

[7] A. T. Grove and O. Rackham, The Nature of Mediterranean Europe. An Ecological History, Yale University, New Haven, Connm, USA, 2001.

[8] J. Pausas, "Mediterranean vegetation dynamics: modelling problems and functional types," Plant Ecology, vol. 140, no. 1, pp. 27-39, 1999.

[9] L. Trabaud, "Man and fire: impacts on Mediterranean vegetation," in Ecosystems of the World 11: Mediterranean-Type Shrublands, F. di Castri, D. W. Goodall, and R. L. Specht, Eds., pp. 523-537, Elsevier, Amsterdam, The Netherlands, 1981.

[10] L. Calvo, L. Baeza, E. Marcos, V. Santana, and V. Papanastasis, "Post-fire management of mediterranean shrublands," in PostFire Management and Restauration of Southern European Forest, F. Moreira, M. Arianoutsou, P. M. Corona, and J. de las Heras, Eds., Springer, New York, NY, USA, 2012.

[11] Ministerio de Medio Ambiente, Segundo Inventario Forestal Nacional, Dirección General de Conservación de la Naturaleza, Madrid, Spain, 1986-1996.

[12] Ministerio de Medio Ambiente, Tercer Inventario Forestal Nacional, Dirección General de Conservación de la Naturaleza, Madrid, Spain, 1997-2007.

[13] A. Moran, Análisis de los cambios espacio-temporales en las unidades de vegetación de la Cordillera Cantábrica (Sector leonés), M.S. thesis, de la Universidad de León, Madrid, Spain, 2007.

[14] L. Calvo, R. Tárrega, and E. de Luis, "Space-time distribution patterns of Erica australis L. subsp. aragonensis (Willk) after experimental burning, cutting, and ploughing," Plant Ecology, vol. 137, no. 1, pp. 1-12, 1998.

[15] L. Calvo, R. Tarrega, E. Luis et al., "Recovery after experimental cutting and burning in three shrub ecosystems situated in a climatic gradient," Plant Ecology, vol. 180, pp. 175-185, 2005.

[16] F. Moreira, F. Rego, and P. Ferreira, “Temporal (1958-1995) pattern of change in a cultural landscape of northwestern Portugal: implications for fire occurrence," Landscape Ecology, vol. 16, no. 6, pp. 557-567, 2001.

[17] W. W. Wessel, A. Tietema, C. Beier, B. A. Emmett, J. Peñuelas, and T. Riis-Nielsen, "A qualitative ecosystem assessment for different shrublands in western Europe under impact of climate change," Ecosystems, vol. 7, no. 6, pp. 662-671, 2004.

[18] P. A. Harrison, "Special issue: ecosystem services and biodiversity conservation," Biodiversity Conservation, vol. 19, no. 10, 2010.

[19] R. Harrington, C. Anton, T. P. Dawson et al., "Ecosystem services and biodiversity conservation: concepts and a glossary," Biodiversity and Conservation, vol. 19, no. 10, pp. 2773-2790, 2010.

[20] L. Calvo, R. Tárrega, and E. Luis, "Secondary succession after perturbations in a shrubland community," Acta Oecologica, vol. 23, no. 6, pp. 393-404, 2002.

[21] L. Calvo, R. Tárrega, and E. Luis, "Twelve years of vegetation changes after fire in an Erica australis community," in Fire Management and landscape Ecology, L. Trabaud, Ed., pp. 123136, International Association of Wildland Fire, Fairfield, Washington, USA, 1998.

[22] W. J. Bond and B. W. van Wilgen, Fire and Plants, Chapman \& Hall, London, UK, 1996.

[23] J. E. Keeley, "Resilience of mediterranean shrub communities to fires," in Resilience in Mediterranean-Type Ecosystems, B. Dell, A. J. M. Hopkins, and B. B. Lamont, Eds., pp. 95-112, W. Junk Publishers, Dordrecht, The Netherlands, 1986.

[24] F. Lloret and M. Vilà, "Clearing of vegetation in Mediterranean garrigue: response after a wildfire," Forest Ecology and Management, vol. 93, no. 3, pp. 227-234, 1997.

[25] T. Navarro, C. L. Alados, and B. Cabezudo, "Changes in plant functional types in response to goat and sheep grazing in two semi-arid shrublands of SE Spain," Journal of Arid Environments, vol. 64, no. 2, pp. 298-322, 2006.

[26] K. J. Elliott, L. R. Boring, W. T. Swank, and B. R. Haines, "Successional changes in plant species diversity and composition after clearcutting a Southern Appalachian watershed," Forest Ecology and Management, vol. 92, no. 1-3, pp. 67-85, 1997.

[27] J. M. de Miguel, L. Ramírez-Sanz, I. Castro, M. Costa-Tenorio, M. A. Casado, and F. D. Pineda, "Plant species richness and spatial organization at different small scales in western Mediterranean landscapes," Plant Ecology, vol. 176, no. 2, pp. 185-194, 2005.

[28] Junta de Castilla y León, Mapa de suelos de Castilla y León, Junta de Castilla y León, Madrid, Spain, 1987.

[29] Ministerio de Agricultura, Caracterización Agroclimática de la Provincia de León, Dirección General de la Producción Agraria, Madrid, Spain, 1980.

[30] A. E. Magurran, Measuring Biological Diversity, Blackwell Publishing, Oxford, Uk, 2004.

[31] R. H. Whittaker, "Evolution and measurement of species diversity," Taxon, vol. 21, pp. 213-251, 1972. 
[32] C. J. F. Ter Braak, "A FORTRAN program for canonical community ordination by/partial/detrended/canonical/correspondence analysis, principal components analysis and redundancy analysis," Tech. Rep. CANOCO (Version 3.12), TNO, Wageningen, The Netherlands, 1991.

[33] E. van der Maarel, "Vegetation dynamics: patterns in time and space," Vegetatio, vol. 77, no. 1-3, pp. 7-19, 1993.

[34] A. Cruz and J. M. Moreno, "Seasonal course of total nonstructural carbohydrates in the lignotuberous Mediterraneantype shrub Erica australis," Oecologia, vol. 128, no. 3, pp. 343350, 2001.

[35] L. Calvo, R. Tárrega, and E. Luis, "Regeneration patterns in a Calluna vulgaris heathland in the Cantabrian mountains (NW Spain): effects of burning, cutting and ploughing," Acta Oecologica, vol. 23, no. 2, pp. 81-90, 2002.

[36] B. Clément and J. Touffet, "Vegetation dynamics in Brittany heathlands after fire," Vegetatio, vol. 46-47, no. 1, pp. 157-166, 1981.

[37] R. M. Cowling, P. W. Rundel, B. B. Lamont, M. K. Arroyo, and M. Arianoutsou, "Plant diversity in mediterranean-climate regions," Trends in Ecology and Evolution, vol. 11, no. 9, pp. 362-366, 1996.

[38] L. F. de Bano and C. E. Conrad, "The effect of fire on nutrients in a chaparral ecosystem," Ecology, vol. 59, pp. 489-497, 1978.

[39] N. K. Suding, "The effects of gap creation on competitive interactions: separating changes in overall intensity from relative rankings," Oikos, vol. 94, no. 2, pp. 219-227, 2001.

[40] M. D. Díaz-Villa, T. Marañón, J. Arroyo, and B. Garrido, "Soil seed bank and floristic diversity in a forest-grassland mosaic in southern Spain," Journal of Vegetation Science, vol. 14, no. 5, pp. 701-709, 2003.

[41] M. Zobel, "The relative role of species pools in determining plant species richness: an alternative explanation of species coexistence?" Trends in Ecology and Evolution, vol. 12, no. 7, pp. 266-269, 1997.

[42] F. Gonzalez-Rabanal and M. Casal, "Effect of high temperatures and ash on germination of ten species from gorse shrubland," Vegetatio, vol. 116, no. 2, pp. 123-131, 1995.

[43] L. Valbuena, R. Tárrega, and E. Luis-Calabuig, "Seed banks of Erica australis and Calluna vulgaris in a heathland subjected to experimental fire," Journal of Vegetation Science, vol. 11, no. 2, pp. 161-166, 2000.

[44] N. R. Webb, "The traditional management of European heathlands," Journal of Applied Ecology, vol. 35, no. 6, pp. 987 990, 1998.

[45] R. Aerts, "Competition between dominant plant species in heathlands," in Heathlands: Patterns and Processes in a Changing Environment, R. Aerts and G. W. Heil, Eds., pp. 125151, Kluwer Academic, Dodrecht, The Netherlands, 1993.

[46] M. Bruggink, "Seed bank, germination and establishment of ericaeous and gramineous species in heathlands," in Heathlands: Patterns and Processes in a Changing Environment, R. Aerts and G. W. Heil, Eds., pp. 153-180, Kluwer Academic, Dodrecht, The Netherlands, 1993.

[47] F. Ojeda, T. Marañón, and J. Arroyo, "Plant diversity patterns in the Aljibe Mountains (S. Spain): a comprehensive account," Biodiversity and Conservation, vol. 9, no. 9, pp. 1323-1343, 2000.

[48] O. W. Archibold, Ecology of World Vegetation, Chapman \& Hall, London, UK, 1995.

[49] W. J. Beese and A. Bryant, "Effect of alternative silvicultural systems on vegetation and bird communities in coastal montane forests of British Columbia, Canada," Forest Ecology and Management, vol. 115, no. 2-3, pp. 231-242, 1999.
[50] G. Decocq, M. Aubert, F. Dupont et al., "Plant diversity in a managed temperate deciduous forest: understorey response to two silvicultural systems," Journal of Applied Ecology, vol. 41, no. 6, pp. 1065-1079, 2004.

[51] S. C. Keeley, J. E. Keeley, S. M. Hutchinson, and A. W. Johnson, "Postfire succession of the herbaceous flora in southern California chaparral,” Ecology, vol. 62, no. 6, pp. 1608-1621, 1981.

[52] P. H. Zedler, "Fire frequency in southern California shrublands: biological effects and management options," in Wildfires in California Brushlands: Ecology and Resource Management, J. E. Keeley and T. Scott, Eds., pp. 101-112, International Association of Wildland Fire, Fairfield, Washington, USA, 1995.

[53] M. A. Huston, "A general hypothesis of species diversity," American Naturalist, vol. 113, pp. 81-101, 1979.

[54] M. A. Huston, Biological Diversity. The Coexistence of Species on Changing Landscapes, Cambridge University Press, Cambridge, UK, 1994. 

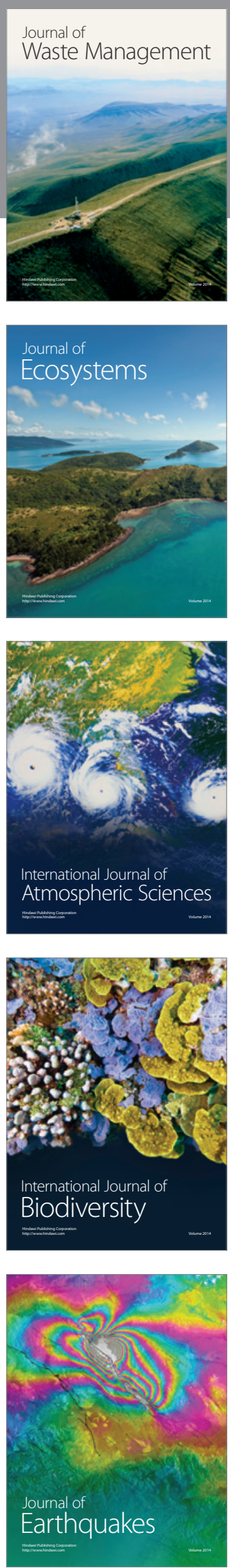
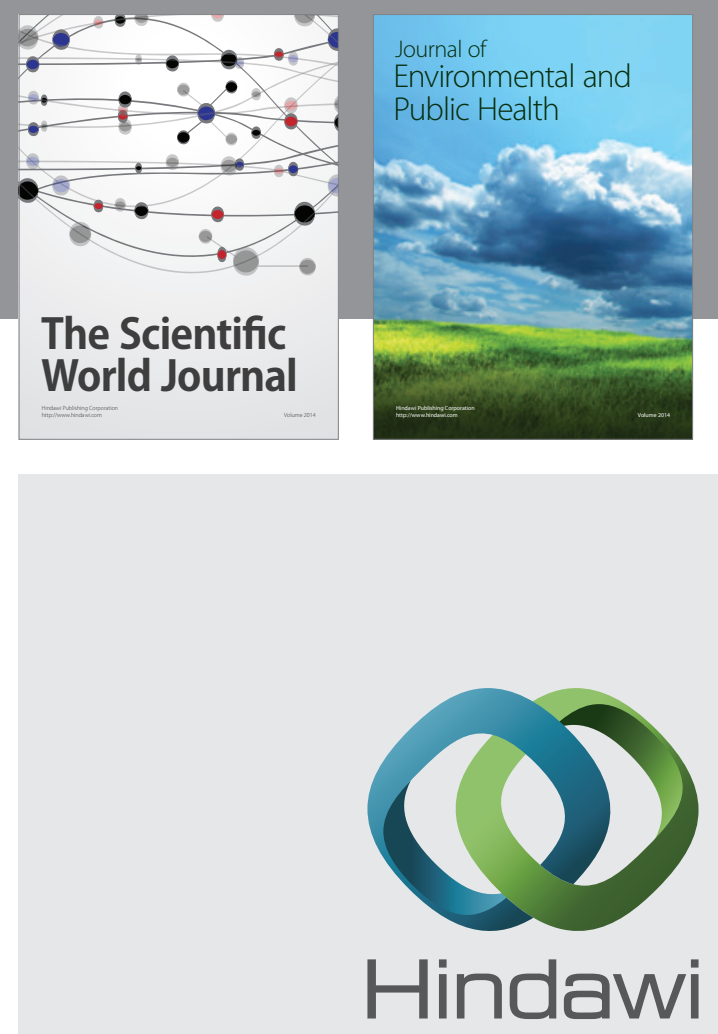

Submit your manuscripts at

http://www.hindawi.com
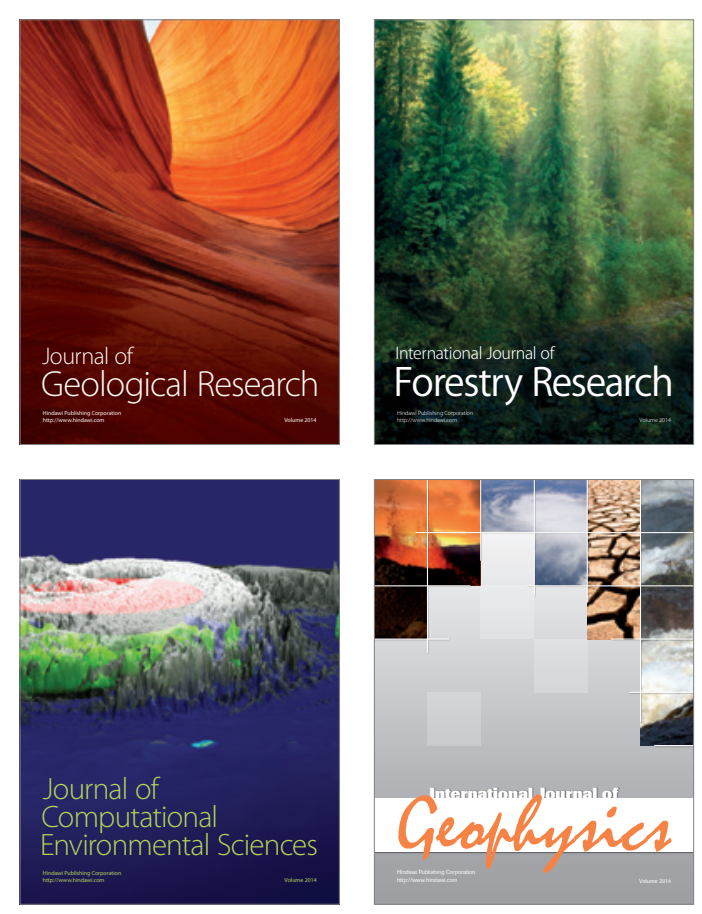
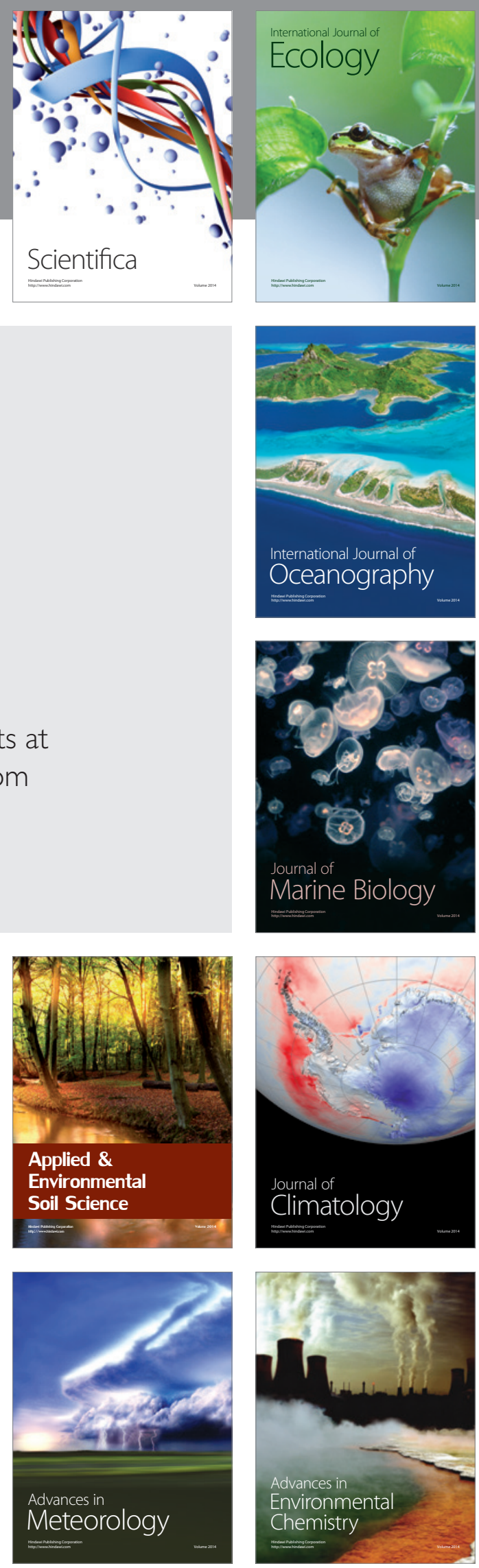